\title{
Cardiovascular manifestations of primary hyperparathyroidism: a narrative review
}

\author{
Jessica Pepe, Cristiana Cipriani, Chiara Sonato, Orlando Raimo, Federica Biamonte \\ and Salvatore Minisola
}

Department of Internal Medicine and Medical Disciplines, 'Sapienza' University, Rome, Italy
Correspondence should be addressed to J Pepe

Email

jessica.pepe@uniroma1.it

\begin{abstract}
Data on cardiovascular disease in primary hyperparathyroidism (PHPT) are controversial; indeed, at present, cardiovascular involvement is not included among the criteria needed for parathyroidectomy. Aim of this narrative review is to analyze the available literature in an effort to better characterize cardiovascular involvement in PHPT. Due to physiological effects of both parathyroid hormone (PTH) and calcium on cardiomyocyte, cardiac conduction system, smooth vascular, endothelial and pancreatic beta cells, a number of data have been published regarding associations between symptomatic and mild PHPT with hypertension, arrhythmias, endothelial dysfunction (an early marker of atherosclerosis), glucose metabolism impairment and metabolic syndrome. However, the results, mainly derived from observational studies, are inconsistent. Furthermore, parathyroidectomy resulted in conflicting outcomes, which may be linked to several potential biases. In particular, differences in the methods utilized for excluding confounding co-existing cardiovascular risk factors together with differences in patient characteristics, with varying degrees of hypercalcemia, may have contributed to these discrepancies. The only meta-analysis carried out in PHPT patients, revealed a positive effect of parathyroidectomy on left ventricular mass index (a predictor of cardiovascular mortality) and more importantly, that the highest pre-operative PTH levels were associated with the greatest improvements. In normocalcemic PHPT, it has been demonstrated that cardiovascular risk factors are almost similar compared to hypercalcemic PHPT, thus strengthening the role of PTH in the cardiovascular involvement. Long-term longitudinal randomized trials are needed to determine the impact of parathyroidectomy on cardiovascular diseases and mortality in PHPT.
\end{abstract}

\section{Introduction}

Primary hyperparathyroidism (PHPT) is typically characterized by elevated serum calcium associated with elevated or non-suppressed levels of parathyroid hormone (PTH) (1). Renal stones, osteoporosis and symptoms related to hypercalcemia are well-known complications (2). Controversy exists regarding the cardiovascular involvement in PHPT, as reported by few previous reviews on this topic, with the most recent published in $2008(3,4,5,6)$. The latest guidelines on PHPT management do not include cardiovascular symptoms among the criteria utilized to consider parathyroidectomy (PTx), mainly due to discordant

Invited author profile

Salvatore Minisola is a full Professor of Internal Medicine at "Sapienza", University of Rome, he is also Head/Chief physician of in-patients and out-patients services at Department of Internal Medicine and Medical Disciplines, Policlinico Umberto I. His special area of interest and expertise include clinical investigation of metabolic bone diseases, most notably osteoporosis and primary hyperparathyroidism. He is the principal investigator of many international trials especially related to experimental new drugs in the field of osteoporosis.

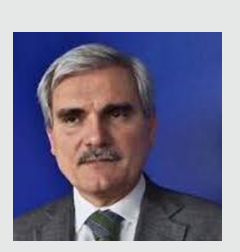

www.eje-online.org DOI: 10.1530/EJE-17-0485
() 2017 European Society of Endocrinology Printed in Great Britain
Published by Bioscientifica Ltd. 
evidences regarding the improvement of cardiovascular abnormalities after surgical intervention (2). Since 2008, new emerging data on cardiovascular manifestations have been published, including those in patients with mild PHPT, which is nowadays the most frequent form of PHPT diagnosed (7) and in normocalcemic primary hyperparathyroidism (NC-PHPT); this last is a new entity recognized in 2009, defined by normal serum calcium levels in the presence of elevated PTH (8), without any recognizable cause of increased hormone values. The categorization of these different forms of PHPT could be considered arbitrary, even though it is important for many aspects (i.e. epidemiological, therapeutic and so on); indeed, some authorities in the field consider PHPT disease as continuum from NC-PHPT to hypercalcemic PHPT.

The purpose of this paper is to review the available literature in an effort to better characterize cardiovascular involvement in PHPT patients and to examine controversies concerning this topic. The authors searched Medline for articles published in English language up until April 30, 2017, with special attention to articles published after 2008 also referring to previous older reviews on this topic whenever possible. The following keywords were used in the search strategy: 'primary hyperparathyroidism' and 'cardiovascular', or 'heart', or 'hypertension', or 'glucose metabolism', or 'arrhythmias,' or 'metabolic syndrome', or 'cardiovascular mortality' or 'parathyroidectomy'.

\section{Effect of calcium and parathyroid hormone on myocyte, conduction system and endothelial cells in physiological conditions}

PTH has been largely recognized as a hormone with vascular and cardiovascular properties and paracrine or autocrine roles in the heart (4). PTH exerts a direct action on cardiac myocytes by activating protein kinase C leading to hypertrophic growth (9). PTH, in animal models, has chronotropic effects (probably due to an increase in the pacemaker current of the sinoatrial node); it influences the coronary blood flow and contractility (10). Calcium also influences the contraction of cardiac myocytes. In normal heart, ionized calcium $\left(\mathrm{Ca}^{++}\right)$enters cells through L-type $\mathrm{Ca}^{++}$channels following each action potential, triggering $\mathrm{Ca}^{++}$release from sarcoplasmatic reticulum (SR) through type 2 ryanodine receptor channels. During diastole, cytosolic $\mathrm{Ca}^{++}$is removed via reuptake in SR and transmembrane extrusion through sodium $\left(\mathrm{Na}^{+}\right)-\mathrm{Ca}^{++}$exchanger. It has been recently demonstrated that an enhanced SR $\mathrm{Ca}^{++}$leak and an increased exchanger activity may increase the risk of supraventricular arrhythmias $(11,12)$.

The effect of calcium and PTH is seen not only on cardiac myocytes but also on vascular smooth cells. PTH exerts its vasodilatatory effects by a direct vasorelaxant mechanism on vascular smooth muscle cells, caused by an inhibition of L-type calcium channels, while calcium is necessary for cell muscle contraction (13). Both calcium and PTH have effects on endothelial cells. PTH is involved in the expression of endothelial pro-atherosclerotic and pro-inflammatory parameters such as receptor advanced glycation end products (Rage) and interleukin 6 (14). It has been demonstrated that PTH stimulates the VEGF 165 mRNA expression, which is implicated in vascular growth, having the potential to accelerate the formation and the progression of vascular atherosclerosis and remodeling (15). There are data suggesting that PTH modulates endothelial function by increasing the production of endothelial nitric oxide synthase and its activity, which involves availability of nitric oxide, a potent vasodilatatory substance (14). Calcium signaling has also a direct role in the regulation of endothelial permeability (16).

\section{Primary hyperparathyroidism and cardiovascular risk factors}

\section{Hypertension}

PHPT has been associated with an increased risk of hypertension, with a prevalence ranging from $40 \%$ to $65 \%(17,18,19,20)$. Controversy exists on the exact mechanism, which underlies the possible link between PHPT and hypertension. Potential explanations include altered renin-angiotensin-aldosterone axis $(21,22,23)$, dysfunction or structural changes in the resistance of vessels documented by altered vasodilatatory response $(24,25)$ and/or enhanced vascular constriction in response to pressor hormones $(26,27)$. A univariate correlation between PTH and mean 24-h systolic blood pressure was found (28); however, this observation could not be confirmed in other PHPT cohorts when multivariate analyses were applied $(29,30)$. Interestingly, a recent paper showed that PHPT independently predicted the risk of hypertension (OR: $1.3, P<0.0001)$ in a population from a large national database of hospital admissions where PHPT was diagnosed in $0.1 \%$ of 37922 admissions (31).

Several studies demonstrated that following PTx, there was a reduction of blood pressure after six months 
(32), one year (33) and up to 5 years (34) while others did not report significant reduction (35). Tomaschitz et al. reported a reduction of blood pressure in PHPT patients followed conservatively with a mineralocorticoid receptor antagonist (eplerenone) with no impact on PTH levels (36).

Due to the variations in published data, which are possibly related to the different criteria used in selecting patients, hypertension is not considered nowadays as a criterion to submit patients to surgery (37). Limited data exist on the effect of PTx on blood pressure in patients with mild PHPT; blood pressure was reduced one year after surgical intervention in one study (38) while it remained stable after 6 months in another investigation $(39,40)$. It should be noted that the only randomized two-year duration study in mild PHPT patients showed neither benefit after PTx nor a deleterious effect on blood pressure with conservative management (41). A few very small retrospective studies analyzed blood pressures in subjects with NC-PHPT, showing the same prevalence of hypertension, which was not statistically different from that found in hypercalcemic patients $(42,43,44)$; however, data on PTx in this last population are lacking.

\section{Glucose metabolism}

The prevalence of type 2 diabetes mellitus in PHPT has been estimated to be approximately $8 \%$, while the prevalence of PHPT in patients with type 2 diabetes mellitus is about 1\%; these figures are higher than those reported in the general population $(45,46)$. The high prevalence of type 2 diabetes mellitus in patients with PHPT was not confirmed in a large cohort of patients, even though the prevalence was still high in a subgroup of older patients and in men (47); differences are probably due to the retrospective nature of the investigation and the lack of appropriate controls (47). More subtle alterations of glucose metabolism, such as glucose intolerance and insulin resistance, have also been described in PHPT patient compared to controls by some $(48,49,50)$, but not by all authors (35). The exact mechanism underlying this association is still unclear. In the general population, alteration of serum calcium homeostasis is significantly correlated with the abnormality of glucose level, insulin resistance and beta-cell function; in particular, calcium influences the affinity of insulin receptor and sensitivity to insulin (51), and PTH concentration is also an independent determinant of insulin sensitivity (52).
PTx improved glucose metabolism in PHPT patients after 6 months $(28,33,53,54)$ or 12 months $(55)$, while other studies did not report such an improvement (56, 57). Considering mild PHPT patients, an increased insulin resistance (HOMA IR) and lower quantitative insulin sensitivity check index (QUICKI) compared to controls, has been reported by some investigators (54); however, these findings were not confirmed by Gianotti et al. (56). PTx in patients with mild PHPT showed no improvement in insulin sensitivity after one year (57, $58,59)$ or 2 years $(41)$. In patients with asymptomatic PHPT, a conservative follow-up of 18 months showed no progression of calcium and glucose metabolism abnormalities (60).

Conflicting results have also been reported in NC-PHPT. Hagström et al. demonstrated that fasting glucose concentrations were significantly higher in the NC-PHPT group, compared to controls, but within the normal reference range (61). Two studies, found no differences in the prevalence of impaired fasting glucose between NC and hypercalcemic patients with PHPT (19, 42). Otzurk et al. showed that NC-PHPT patients had similar prevalence of glucose intolerance compared with hypercalcemic PHPT patients, but found a significantly higher prevalence compared with controls (43). This study reported no statistically significant difference concerning mean fasting serum insulin and glycosylated hemoglobin levels (43), in agreement with the results obtained by Hagstorm et al. concerning the last parameter (61). Long-term conservative follow-up of NC-PHPT demonstrated no worsening in glucose metabolism after 4 years, while data on the role of PTx in this setting are missing (62). The heterogeneity of these findings may be a reflection of different parameters utilized to investigate glucose metabolism abnormalities (i.e. insulin resistance, fasting blood glucose or glycosylated hemoglobin).

\section{Atherosclerosis}

Several surrogates of early atherosclerosis have been investigated in PHPT; high levels of serum PTH have been related to atherogenesis in the general population possibly via vascular calcification and remodeling, through direct PTH receptor interaction on the vessels as well as indirectly via inflammation and vascular dysfunction (63). Flow-mediated dilatation (FMD) of brachial artery, a 'gold standard' of endothelial dysfunction also considered a surrogate marker of atherosclerosis, has been reported to be impaired in 
PHPT patients improving after PTx $(24,25)$. FMD has been shown to be negatively correlated with serum calcium levels (64). In contrast, some authors found no improvement in the FMD 3 years after PTx (26).

Concerning patients with mild PHPT, FMD was impaired compared to controls; negatively correlated with calcium and PTH and improved significantly after PTx (65). Contrary to these observations, Carrelli et al. demonstrated that FMD was normal in patients with mild PHPT and was unchanged one year after PTx; however, among those who had impaired FMD at baseline, a significant improvement was observed following PTx (66).

Endothelial dysfunction can also directly contribute to vessel stiffening and reduced arterial elasticity; indeed, arterial stiffness is considered an early marker of atherosclerosis. In one study, PHPT patients were characterized by significantly higher mean values of arterial stiffness compared to controls $(67,68)$, that improved 6 months after PTx (67). However, Rosa et al. hypothesized that this effect may be determined primarily by improved blood pressure control after surgery (68). Mild PHPT 'per se' has been considered a stronger predictor of increased aortic stiffness compared to other traditional cardiovascular risk factors being associated with the degree of PTH elevations $(69,70)$. However, Barletta et al. did not report any difference in aortic stiffness in PHPT patients compared to controls (40). There was a long-term improvement of pulse wave velocity, a marker of aortic stiffness, after PTx in one study (71); however, Cansu et al. demonstrated that this was accounted for by changes in blood pressure post-operatively (72). Normocalcemic PHPT seems to be characterized by similar arterial stiffness values compared to hypercalcemic PHPT patients; the effect of PTx in this population has not yet been investigated (19).

\section{Metabolic syndrome}

The prevalence of metabolic syndrome (MS) has been shown to increase the risk of cardiovascular disease in the general population (73). In symptomatic PHPT, the prevalence of MS seems to be similar or higher compared to control populations $(35,74)$, ranging from $8 \%$ to $59 \%$ $(75,76)$. These different percentages may arise from the inclusion in the population studied of both female and male subjects of different ages. There are several papers that investigated the change of each component of MS after PTx, but only Ishay et al. reported the effect on
MS one year after surgery in patients with PHPT (35). They showed no impact on MS prevalence after PTx, but when adjusted for age and waist circumference, patients with severe PHPT had a 14.2-fold increased risk of MS compared to controls, which decreased to 1.3 following PTx (35).

In mild PHPT, Luboshitzky et al. showed that the prevalence of MS was lower (34.3\%) compared to symptomatic PHPT (37.5\%) (77); however, Procopio et al. reported a significantly higher prevalence (47.6\%) in asymptomatic PHPT patients, with low-risk of end-organ damage, compared to symptomatic PHPT (8.7\%) (50). Moreover, both BMI and the presence of a low-risk asymptomatic PHPT disease predicted MS after adjusting for age and sex (50). In PHPT patients with MS, Delfini et al. showed higher mean values of leptin and lower adiponectin serum level compared to controls (78); these findings are interesting because an interaction between adipokines and bone metabolism has been recently suggested in the general population (79).

In asymptomatic PHPT, a significant reduction of MS was seen by Luigi et al. (38\% vs 28\%) 6 months following PTx (28). NC-PHPT patients had similar prevalence of MS, evaluated using International Diabetes Federation (IDF) 2006 criteria, compared to hypercalcemic PHPT, without difference compared to controls (43). Hagström et al. reported separately the criteria needed for the diagnosis of MS; they showed that in NC-PHPT, there was an increase in proatherogenic lipoprotein levels, BMI and glucose levels compared to age-matched controls; PTx had positive effects only on proatherogenic lipoprotein levels in contrast with conservative treatment (61).

\section{Primary hyperparathyroidism and cardiovascular abnormalities}

\section{Structural heart involvement}

Cardiac dysfunction has been reported in patients with PHPT, distinctly involving the diastolic and systolic ventricular function, as illustrated by previous reviews including studies carried out before 2008 (3, 4, 5). After 2008 several studies were published; in particular, in 2010, Farahnk et al. reported no significant abnormalities in left ventricular ejection fraction, fractional shortening and left ventricular end-systolic volume (80). Two studies carried out in patients with mild PHPT showed no diastolic dysfunction $(81,82)$. Persson et al. carried out 
the only randomized study to investigate the effect of PTx on these parameters in mild PHPT patients, showing no benefits after surgery (82). A recent study utilizing new methods to detect global ventricular performance (which include both diastolic and systolic function) showed an impaired global ventricular function in PHPT patients when also considering those with the mild form of the disease (83). Left ventricular mass index (LVMI), a well-known risk factor for cardiovascular mortality in the general population (84), has been extensively studied in this glandular disorder, and observed to be increased in some but not all studies, as reported by previous reviews on this topic $(3,4,5,81)$. A recent metaanalysis carried out in PHPT patients by Mc Maohn et al., which included 15 studies for a total of 457 patients enrolled, showed that six months after PTx, there was an average 12.5 LVMI reduction; more importantly, the highest pre-operative PTH levels were related with the greatest improvements (85). However, this meta-analysis included patients of both genders and considered both mild PHPT patients together with those who met surgical criteria. A recent study showed that cardiac remodeling was associated with low-grade inflammation (86); furthermore, bone turnover markers, such as N-terminal propeptide of procollagen type 1 (P1NP), osteocalcin (OC), bone-specific alkaline phosphatase (BALP) or betacrosslaps (CTX) appeared to be associated with systolic and diastolic function (87). Another peculiar finding documented in PHPT patients is myocardial and valvular calcification, also highlighted in initial reviews on this topic $(3,4,5)$.

Interestingly, the only paper published after 2008 on this topic showed that in mild PHPT, aortic calcification was predicted by PTH and not by calcium levels, after corrections for well-known cardiovascular risk factors (88). So far, there are no studies in NC-PHPT regarding structural heart involvement.

\section{Cardiac conduction abnormalities and arrhythmias}

It is well known that hypercalcemia may induce electrocardiogram abnormalities such as QT interval shortening, sometimes associated with prolongation of PR interval and QRS duration (89). A short QT is associated with increased risk of arrhythmias and sudden cardiac death (90); furthermore, and more importantly, it has been recently shown that QT interval duration is associated with increased mortality risk, even within the normal reference range in the general population (91). The presence of arrhythmias in PHPT patients has been reported, so far, mainly as case reports $(92,93)$. Indeed, it is difficult to ascertain symptoms reported by patients that may arise suddenly and last only a few minutes. Nilsson et al. (25) showed an increased incidence of ventricular premature beats (VPBs) during the exercise test, which is an experimental method that physiologically induces a further shortening of QT; however, patients with diabetes or ischemic heart disease were also included. We carried out a study excluding patients with these disorders to avoid potential biases. We found that PHPT was associated with VPBs during stress testing; furthermore, serum calcium level was a predictor of VPBs during peak exercise (94), even if mean QT values were normal in the PHPT group, but significantly shorter compared with controls. It should be noted that in our study only 6 patients out of 30, had serum calcium values $1 \mathrm{mg} / \mathrm{dL}$ above the normal range. Nilsson et al. evaluating the effect of PTx on VPBs did not find significant changes in prevalence; it is worthy to underline that the investigators enrolled patients with coronary artery disease and diabetes (25). Our randomized study, carried out under strict exclusion criteria to avoid potential biases, showed a reduction of VPBs and a restored physiological QT dynamics, 6 months after PTx, as evaluated by exercise test (95). In this context, Birgander et al. demonstrated a previously unknown impairment of catecholamine response to physical stress test in PHPT patients along with changes of heart rate variability, a predictor of arrhythmias, that was reversed 6 months following PTx (96). Similar findings were reported by Curione et al.; they evaluated the 24-h Holter ECG, investigating sympatho-vagal balance (heart rate variability and QT parameters) in asymptomatic PHPT patients compared to controls (97). The enhanced sympathetic tone (shorter QTc interval, higher QTc dispersion and lack of physiological adaptation of QT length to R-R interval), was restored 18 months following PT, but not after 4 months $(97,98)$. There are no studies, so far, regarding arrhythmic risk in NC-PHPT patients.

\section{Primary hyperparathyroidism and large vessel involvement}

Mean carotid intima-media thickness (IMT) values, considered a strong predictor of systemic atherosclerosis and cerebrovascular events, have been shown to be elevated by some authors in patients with PHPT $(65,99$, $100,101)$. However, most authors did not find carotid structural changes in PHPT $(24,25,40,49,102,103$, 
$104,105)$, nor did PTx seem to have significant effects $(24,25,40,104)$ on this parameter, except in one study (33).

In mild PHPT patients, PTx was found to improve IMT values according to Tuna et al. (65), but not to Ring et al. (105). Walker et al. showed improvement only in patients with abnormal IMT at baseline (106). In NC-PHPT, mean carotid IMT values were significantly higher (regardless of serum calcium values) compared to controls; PTx led to an improvement in IMT only in hypercalcemic patients and not in NC-PHPT (72).

With regards to abdominal aortic calcification, postmenopausal symptomatic PHPT patients had a higher prevalence compared to weight, age- and sex-matched controls, which correlated with higher PTH levels (107). No data on mild and NC-PHPT patients are currently available.

Considering the coronary artery district, Streeten etal. did not find significant coronary artery calcification utilizing a computed tomography scan (108) while Osto et al. detected microvascular dysfunction using a transthoracic Doppler (109). A recent study evaluating myocardial perfusion, conducted by gated singlephoton emission computed tomography, demonstrated that coronary flow reserve is significantly reduced in PHPT patients without coronary artery disease compared to controls and was dependent on disease duration (110).

In symptomatic PHPT patients, six months after PTx, there was no improvement of coronary artery calcification; however, half of the patients studied were affected by hypertension and dyslipidemia (111). In a study carried out with transthoracic Doppler, 6 months following PTx, a reduction in microvascular dysfunction was reported; PTH, age and heart rate were independently associated with microvascular dysfunction and not with disease duration (109). In the only study performed in mild PHPT, by Kepez et al., coronary calcification scores of hypertensive PHPT patients were significantly higher than both normotensive PHPT patients and controls (112). There was no significant difference regarding calcification scores of normotensive PHPT patients vs controls. Coronary artery calcifications have not been studied in NC-PHPT.

\section{Primary hyperparathyroidism and mortality for cardiovascular disease}

Studies carried out in cohorts enrolled during the last millennium, showed normal or higher cardiovascular mortality in PHPT patients compared to general population, with different outcomes related to PTx, as previously reviewed $(3,4,5)$. More recently, CliftonBligh et al. studied PHPT patients between 1961 and 1994 prospectively until 2011. They showed that both surgically treated and non-surgically treated patients have an increased risk of mortality, independently of serum calcium. They also emphasized that other factors had a significant impact on mortality, such as, the presence of diabetes mellitus, coronary heart disease and hypertension (113). Therefore, differences in mortality in studies examining the impact of PHPT on morbidity may be ascribed to different incidence of these conditions in the populations studied. In a retrospective population based observational study of mild PHPT patients (PEARS), selected from a cohort between 1997 and 2006, both cardiovascular morbidity and mortality ratio appeared to be increased (114), contrary to several studies carried out before the ' 90 $(115,116)$. These authors, in an effort to identify the best biochemical risk factors alongside other factors for predicting adverse outcomes in untreated PHPT patients showed that calcium was associated with increased risk of all-cause mortality in the short term but had no significant impact on other outcomes, while baseline PTH, rather than calcium, best predicts long-term outcomes (117). Thus, the question remains unresolved as to which of the two, i.e. calcium or PTH, is mainly responsible for higher mortality in PHPT patients. Unfortunately, there are no data in the current literature on mortality in NC-PHPT, which could help to answer this question and to better understand the role of high PTH in the presence of normocalcemia. However, a recent meta-analysis, in the general population, indicates that higher serum levels of PTH are associated with increased risk of fatal cardiovascular disease events (118).

\section{Perspective}

The evidence accumulated so far, seems to suggest a high cardiovascular risk in PHPT, through different mechanisms (Fig. 1). However, the vast majority of the studies conducted so far are observational, crosssectional, single-center studies, not randomized. After 2008, only three randomized trials were carried out: two involving mild PHPT, suggesting neither improvement on both blood pressure and insulin sensitivity (41), nor a significant improvement in cardiac structure (82) after 


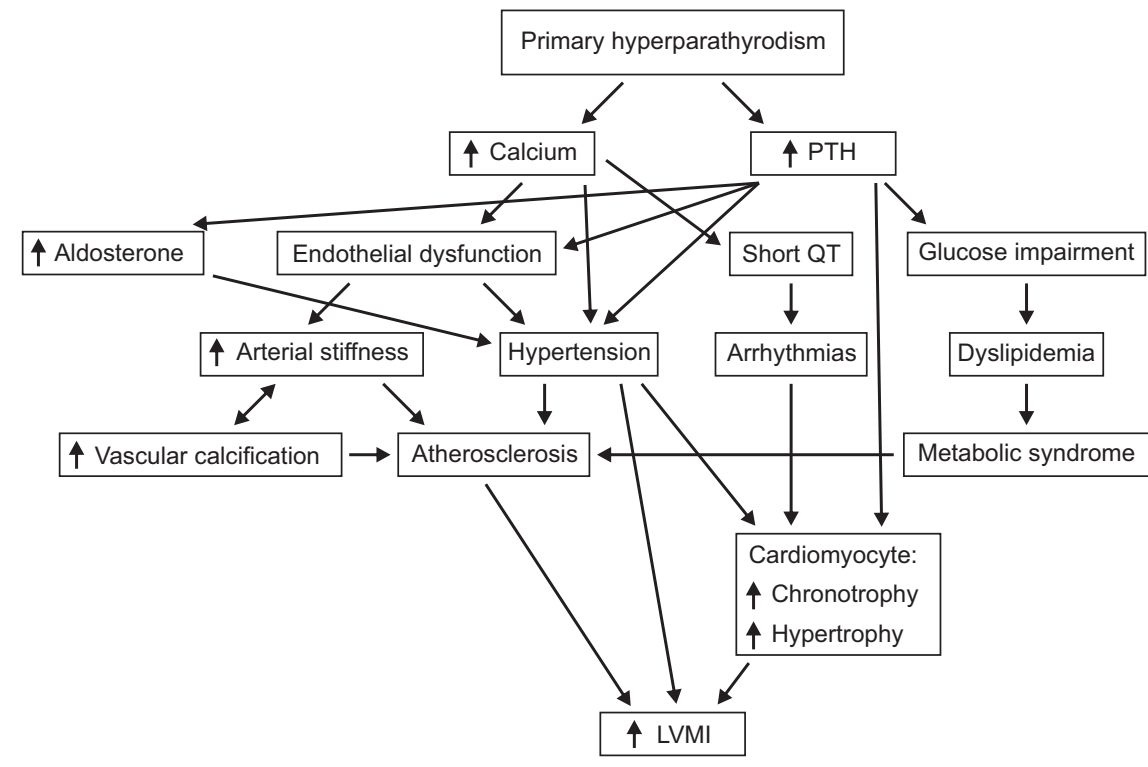

\section{Figure 1}

Proposed mechanisms behind the observed increase risk in cardiac disease associated with primary hyperparathyroidism.
PTx; the third one involving symptomatic PHPT, which demonstrates reduction of arrhythmias following PTx (95). For this reason, further longitudinal randomized studies are needed to determine whether or not cardiovascular involvement should be included among the criteria for recommending PTx; the same could apply to the different nontraditional manifestations of PHPT reported in the literature (119). It would also be important to analyze the possible differences in cardiovascular risk factors related to gender, different countries, hereditary forms of PHPT and effects of drugs such as cinacalcet; indeed, these differences have already been shown to impact the classical manifestation of the diseases (120, $121,122,123,124)$.

\section{Conclusion}

The reasons for discordant prevalence of cardiovascular risk factors in PHPT, discussed in this review, are not fully understood. Differences in the methods employed for excluding the influence of co-existing cardiovascular risk factors as well as differences in patient characteristics with varying degrees of hypercalcemia may have contributed to discrepancies. It could be hypothesized that PHPT might induce structural abnormalities during the course of the disease; therefore, parathyroidectomy could be effective only if performed in the early phase of disease. The extent and the nature of cardiovascular involvement in those with symptomatic PHPT have been better characterized compared to mild PHPT and NC-PHPT patients; in the latter conditions, there are too limited data to provide a comprehensive picture. However, if we consider NC-PHPT an early stage of hypercalcemic PHPT, research should mainly focused on this population. If a cardiovascular examination becomes a standard evaluation of PHPT patients, it would be possible to obtain a definitive prevalence of cardiovascular risks and consequently discover more subtle impairment, as it has been the case for kidney and skeletal involvement. Indeed, the adoption of a routine imaging examination as part of the standard management of PHPT patients, even in the asymptomatic cases $(37,125)$, has changed the prevalence of the classical complications.

Declaration of interest

The authors declare that there is no conflict of interest that could be perceived as prejudicing the impartiality of the research reported.

\section{Funding}

This research did not receive any specific grant from any funding agency in the public, commercial or not-for-profit sector.

\section{References}

1 Minisola S, Pepe J, Piemonte S \& Cipriani C. The diagnosis and management of hypercalcaemia. BMJ 2015350 h2723. (doi:10.1136/ bmj.h2723)

2 Khan AA, Hanley DA, Rizzoli R, Bollerslev J, Young JE, Rejnmark L, Thakker R, D'Amour P, Paul T, Van Uum S et al. Primary hyperparathyroidism: review and recommendations on evaluation, diagnosis, and management. A Canadian and international consensus. Osteoporosis International 201728 1-19. (doi:10.1007/ s00198-016-3716-2)

3 Andersson P, Rydberg E \& Willenheimer R. Primary hyperparathyroidism and heart disease-a review. European Heart Journal 200425 1776-1787. (doi:10.1016/j.ehj.2004.07.010)

4 Fitzpatrick LA, Bilezikian JP \& Silverberg SJ. Parathyroid hormone and the cardiovascular system. Current Osteoporosis Report 20086 77-83. (doi:10.1007/s11914-008-0014-8) 
5 Walker MD \& Silverberg SJ. Cardiovascular aspects of primary hyperparathyroidism. Journal of Endocrinological Investigation 200831 925-931. (doi:10.1007/BF03346443)

6 Ybarra J, Doñate T, Jurado J \& Pou JM. Primary hyperparathyroidism, insulin resistance, and cardiovascular disease: a review. Nursing Clinics of North America 200742 79-85. (doi:10.1016/j. cnur.2006.11.010)

7 Silverberg SJ, Clarke BL, Peacock M, Bandeira F, Boutroy S, Cusano NE, Dempster D, Lewiecki EM, Liu JM, Minisola S et al. Current issues in the presentation of asymptomatic primary hyperparathyroidism: proceedings of the Fourth International Workshop. Journal of Clinical Endocrinology and Metabolism 201499 3580-3594. (doi:10.1210/jc.20141415)

8 Cusano NE, Silverberg SJ \& Bilezikian JP. Normocalcemic primary hyperparathyroidism. Journal of Clinical Densitometry 201316 33-39. (doi:10.1016/j.jocd.2012.12.001)

9 Schluter KD \& Piper HM. Cardiovascular actions of parathyroid hormone and parathyroid hormone-related peptide. Cardiovascular Research 199837 34-41. (doi:10.1016/S0008-6363(97)00194-6)

10 Dipette DJ, Christenson W, Nickols MA \& Nickols GA. Cardiovascular responsiveness to parathyroid hormone (PTH) and PTH-related protein in genetic hypertension. Endocrinology 1992130 2045-2051. (doi:10.1210/en.130.4.2045)

11 El-Sherif N \& Turitto G. Electrolyte disorders and arrhythmogenesis. Cardiology Journal 201118 233-2345.

12 Voigt N, Li N, Wang Q, Wang W, Trafford AW, Abu-Taha I, Sun $\mathrm{Q}$, Wieland T, Ravens $\mathrm{U}$, Nattel S et al. Enhanced sarcoplasmic reticulum $\mathrm{Ca} 2+$ leak and increased $\mathrm{Na}+-\mathrm{Ca} 2+$ exchanger function underlie delayed afterdepolarizations in patients with chronic atrial fibrillation. Circulation 2012125 2059-2070. (doi:10.1161/ CIRCULATIONAHA.111.067306)

13 Pang PKT, Wang R, Shan J, Karpinski E \& Benishin CG. Specific inhibition of long-lasting, L-type calcium channels by synthetic parathyroid hormone. PNAS 199087 623-627. (doi:10.1073/ pnas.87.2.623)

14 Rashid G, Bernheim J, Green J \& Benchetrit S. Parathyroid hormone stimulates endothelial expression of atherosclerotic parameters through protein kinase pathways. American Journal of Physiology: Renal Physiology 2007292 F1215-F1218. (doi:10.1152/ ajprenal.00406.2006)

15 Rashid G, Bernheim J, Green J \& Benchetrit S. Parathyroid hormone stimulates the endothelial expression of vascular endothelial growth factor. European Journal of Clinical Investigation 200838 798-803. (doi:10.1111/j.13652362.2008.02033.x)

16 Lum H \& Malik AB. Regulation of vascular endothelial barrier function. American Journal of Physiology 1994267 223-241.

17 Heyliger A, Tangpricha V, Weber C \& Sharma J. Parathyroidectomy decreases systolic and diastolic blood pressure in hypertensive patients with primary hyperparathyroidism. Surgery 2009146 1042-1047. (doi:10.1016/j.surg.2009.09.024)

18 Schiffl H \& Lang SM. Hypertension secondary to PHPT: cause or coincidence? International Journal of Endocrinology 201120116. (doi:10.1155/2011/974647)

19 Tordjman KM, Yaron M, Izkhakov E, Osher E, Shenkerman G, Marcus-Perlman Y \& Stern N. Cardiovascular risk factors and arterial rigidity are similar in asymptomatic normocalcemic and hypercalcemic primary hyperparathyroidism. European Journal of Endocrinology 2010162 925-933. (doi:10.1530/EJE-09-1067)

20 Letizia C, Ferrari P, Cotesta D, Caliumi C, Cianci R, Cerci S, Petramala L, Celi M, Minisola S, D'Erasmo E et al. Ambulatory monitoring of blood pressure (AMBP) in patients with primary hyperparathyroidism Journal of Human Hypertension 200519 901-906. (doi:10.1038/ sj.jhh.1001907)

21 Brunaud L, Germain A, Zarnegar R, Rancier M, Alrasheedi S, Caillard C, Ayav A, Weryha G, Mirallie E \& Bresler L. Serum aldosterone is correlated positively to parathyroid hormone (PTH) levels in patients with primary hyperparathyroidism. Surgery 2009146 1035-1041. (doi:10.1016/j.surg.2009.09.041)

22 Verheyen N, Fahrleitner-Pammer A, Pieske B, Meinitzer A, Belyavskiy E, Wetzel J, Gaksch M, Grübler MR, Catena C, Sechi LA et al. Parathyroid hormone, aldosterone-to-renin ratio and fibroblast growth factor-23 as determinants of nocturnal blood pressure in primary hyperparathyroidism: the eplerenone in primary hyperparathyroidism trial. Journal of Hypertension $2016 \mathbf{3 4} 1778$ 1786. (doi:10.1097/hjh.0000000000001004)

23 Tomaschitz A, Ritz E, Pieske B, Rus-Machan J, Kienreich K, Verheyen N, Gaksch M, Grübler M, Fahrleitner-Pammer A, Mrak P et al. Aldosterone and parathyroid hormone interactions as mediators of metabolic and cardiovascular disease. Metabolism 201463 20-31. (doi:10.1016/j.metabol.2013.08.016)

24 Kosch M, Hausberg M, Vormbrock K, Kisters K, Gabriels G, Rahn $\mathrm{KH} \&$ Barenbrock M. Impaired flow mediated vasodilation of the brachial artery in patients with primary hyperparathyroidism improves after parathyroidectomy. Cardiovascular Research 200047 813-818. (doi:10.1016/S0008-6363(00)00130-9)

25 Nilsson IL, Aberg J, Rastad J \& Lind L. Endothelial vasodilatory dysfunction in primary hyperparathyroidism is reversed after parathyroidectomy. Surgery 1999126 1049-1055. (doi:10.1067/ msy.2099.101422)

26 Neunteufl T, Heher S, Prager G, Katzenschlager R, Abela C, Niederle B \& Stefenelli T. Effects of successful parathyroidectomy on altered arterial reactivity in patients with hypercalcaemia: results of a 3-year follow-up study. Clinical Endocrinology 200053 229-233. (doi:10.1046/j.1365-2265.2000.01076.x)

27 Rodriguez-Portales JA \& Fardella C. Primary hyperparathyroidism and hypertension: persistently abnormal pressor sensitivity in normotensive patients after surgical cure. Journal of Endocrinological Investigation 199417 307-311. (doi:10.1007/BF03348986)

28 Luigi P, Chiara FM, Laura Z, Cristiano M, Giuseppina C, Luciano C, Giuseppe P, Sabrina C, Susanna S, Antonio C et al. Arterial hypertension, metabolic syndrome and subclinical cardiovascular organ damage in patients with asymptomatic primary hyperparathyroidism before and after parathyroidectomy: preliminary results. International Journal of Endocrinology 20122012 1-10. (doi:10.1155/2012/408295)

29 Lumachi F, Camozzi V, Luisetto G, Zanella S \& Basso SMM. Arterial blood pressure, serum calcium and PTH in elderly men with parathyroid tumors and primary hyperparathyroidism. Anticancer Research 201131 3969-3972.

30 Lumachi F, Ermani M, Luisetto G, Nardi A, Basso SM, Camozzi V \& Favia G. Relationship between serum parathyroid hormone, serum calcium and arterial blood pressure in patients with primary hyperparathyroidism: results of a multivariate analysis. European Journal of Endocrinology 2002146 643-647. (doi:10.1530/ eje.0.1460643)

31 Kalla A, Krishnamoorthy P, Gopalakrishnan A, Garg J, Patel NC \& Figueredo VM. Primary hyperparathyroidism predicts hypertension: results from the National Inpatient Sample. International Journal of Cardiology 2017227 335-337. (doi:10.1016/j.ijcard.2016.11.080)

32 Rydberg E, Birgander M, Bondeson A, Bondeson L \& Willenheimer R. Effect of successful parathyroidectomy on 24-h ambulatory blood pressure in patients with primary hyperparathyroidism. International Journal of Cardiology 2010142 15-21. (doi:10.1016/j. ijcard.2008.12.027)

33 Karakose M, Caliskan M, Arslan MS, Demirci T, Karakose S \& Cakal E. The impact of parathyroidectomy on serum ADAMTS1, ADAMTS4 levels, insulin resistance, and subclinical cardiovascular disease in primary hyperparathyroidism. Endocrine 201755 283-288. (doi:10.1007/s12020-016-1175-3)

34 Nilsson IL, Aberg J, Rastad J \& Lind L. Maintained normalization of cardiovascular dysfunction 5 years after parathyroidectomy 
in primary hyperparathyroidism. Surgery 2005137 632-638. (doi:10.1016/j.surg.2005.02.001)

35 Ishay A, Herer P \& Luboshitzky R. Effects of successful parathyroidectomy on metabolic cardiovascular risk factors in patients with severe primary hyperparathyroidism. Endocrine Practice 201117 584-590. (doi:10.4158/EP10321.OR)

36 Tomaschitz A, Verheyen N, Meinitzer A, Pieske B, Belyavskiy E, Brussee H, Haas J, März W, Pieske-Kraigher E, Verheyen S et al. Effect of eplerenone on parathyroid hormone levels in patients with primary hyperparathyroidism: results from the EPATH randomized, placebo-controlled trial. Journal of Hypertension 201634 1347-1356. (doi:10.1097/HJH.0000000000000927)

37 Bilezikian JP, Brandi ML, Eastell R, Silverberg SJ, Udelsman R, Marcocci C \& Potts JT Jr. Guidelines for the management of asymptomatic primary hyperparathyroidism: summary statement from the Fourth International Workshop. Journal of Clinical Endocrinology and Metabolism 201499 3561-3569. (doi:10.1210/ jc.2014-1413)

38 Feldstein CA, Akopian M, Pietrobelli D, Olivieri A \& Garrido D. Long-term effects of parathyroidectomy on hypertension prevalence and circadian blood pressure profile in primary hyperparathyroidism. Clinical and Experimental Hypertension 201032 154-158. (doi:10.3109/10641960903254471)

39 Farahnak P, Lärfars G, Sten-Linder M \& Nilsson IL. Mild primary hyperparathyroidism: vitamin D deficiency and cardiovascular risk markers. Journal of Clinical Endocrinology and Metabolism 2011296 2112-2118. (doi:10.1210/jc.2011-0238)

40 Barletta G, De Feo ML, Del Bene R, Lazzeri C, Vecchiarino S, La Villa G, Brandi ML \& Franchi F. Cardiovascular effects of parathyroid hormone: a study in healthy subjects and normotensive patients with mild primary hyperparathyroidism. Journal of Clinical Endocrinology and Metabolism 200085 1815-1821. (doi:10.1210/ jc.85.5.1815)

41 Bollerslev J, Rosen T, Mollerup CL, Nordenström J, Baranowski M, Franco C, Pernow Y, Isaksen GA, Godang K, Ueland T et al. Effect of surgery on cardiovascular risk factors in mild primary hyperparathyroidism. Journal of Clinical Endocrinology and Metabolism 200994 2255-2261. (doi:10.1210/jc.2008-2742)

42 Tuna MM, Çalışkan M, Ünal M, Demirci T, Doğan BA, Küçükler K, Özbek M, Berker D, Delibaşı T \& Güler S. Normocalcemic hyperparathyroidism is associated with complications similar to those of hypercalcemic hyperparathyroidism. Journal of Bone and Mineral Metabolism 201634 331-335. (doi:10.1007/s00774-015 -0673-3)

43 Yener Ozturk F, Erol S, Canat MM, Karatas S, Kuzu I, Dogan Cakir S \& Altuntas Y. Patients with normocalcemic primary hyperparathyroidism may have similar metabolic profile as hypercalcemic patients. Endocrine Journal 201663 111-118. (doi:10.1507/endocri.EJ15-0392)

44 Chen G, Xue Y, Zhang Q, Xue T, Yao J, Huang H, Liang J, Li L, Lin W, Lin $\mathrm{L}$ et al. Is normocalcemic primary hyperparathyroidism harmful or harmless? Journal of Clinical Endocrinology and Metabolism 2015 100 2420-2424. (doi:10.1210/jc.2014-4432)

45 Taylor WH. The prevalence of diabetes mellitus in patients with primary hyperparathyroidism and among their relatives. Diabetic Medicine 19918 683-687. (doi:10.1111/j.1464-5491.1991.tb01678.x)

46 Taylor WH \& Khaleeli AA. Prevalence of primary hyperparathyroidism in patients with diabetes mellitus. Diabetic Medicine 199714 386-389. (doi:10.1002/(SICI)10969136(199705) 14:5<386::AID-DIA362>3.0.CO;2-3)

47 Cardenas MG, Vigil KJ, Talpos GB, Lee MW, Peterson E \& Rao DS. Prevalence of type 2 diabetes mellitus in patients with primary hyperparathyroidism. Endocrine Practice 200814 69-75. (doi:10.4158/EP.14.1.69)

48 Kumar S, Olukoga AO, Gordon C, Mawer EB, France M, Hosker JP, Davies M \& Boulton AJ. Impaired glucose tolerance and insulin insensitivity in primary hyperparathyroidism. Clinical Endocrinology 199440 47-53. (doi:10.1111/j.1365-2265.1994. tb02442.x)

49 Stamatelopoulos K, Athanasouli F, Pappa T, Labrinoudaki I, Papamichael C, Polymeris A, Georgiopoulos G, Vemmou A, Sarika L, Terpos E et al. Hemodynamic markers and subclinical atherosclerosis in postmenopausal women with primary hyperparathyroidism. Journal of Clinical Endocrinology and Metabolism 201499 2704-2711. (doi:10.1210/jc.2013-4273)

50 Procopio M, Barale M, Bertaina S, Sigrist S, Mazzetti R, Loiacono M, Mengozzi G, Ghigo E \& Maccario M. Cardiovascular risk and metabolic syndrome in primary hyperparathyroidism and their correlation to different clinical forms. Endocrine 201447 581-589. (doi:10.1007/s12020-013-0091-z)

51 Sun G, Vasdev S, Martin GR, Gadag V \& Zhang H. Altered calcium homeostasis is correlated with abnormalities of fasting serum glucose, insulin resistance, and beta-cell function in the Newfoundland population. Diabetes 200554 3336-3339. (doi:10.2337/diabetes.54.11.3336)

52 Chiu KC, Chuang LM, Lee NP, Ryu JM, McGullam JL, Tsai GP \& Saad MF. Insulin sensitivity is inversely correlated with plasma intact parathyroid hormone level. Metabolism 200049 1501-1505. (doi:10.1053/meta.2000.17708)

53 Cvijovic G, Micic D, Kendereski A, Milic N2, Zoric S, SumaracDumanovic M, Stamenkovic-Pejkovic D, Polovina S, Jeremic D \& Gligic A. The effect of parathyroidectomy on insulin sensitivity in patients with primary hyperparathyroidism - an never ending story? Experimental and Clinical Endocrinology and Diabetes 2015123 336-341. (doi:10.1053/meta.2000.17708)

54 Tassone F, Procopio M, Gianotti L, Visconti G, Pia A, Terzolo M \& Borretta G. Insulin resistance is not coupled with defective insulin secretion in primary hyperparathyroidism. Diabetic Medicine 200926 968-973. (doi:10.1111/j.1464-5491.2009.02804.x)

55 Norenstedt S, Pernow Y, Brismar K, Sääf M, Ekip A, Granath F, Zedenius \& Nilsson IL. Primary hyperparathyroidism and metabolic risk factors, impact of parathyroidectomy and vitamin D supplementation, and results of a randomized double-blind study. European Journal of Endocrinology 201369 795-804. (doi:10.1530/ EJE-13-0547)

56 Gianotti L, Tassone F, Baffoni C, Pellegrino M, Cassibba S, Castellano E, Magro G, Cesario F, Visconti G \& Borretta G. Relationship between insulin sensitivity and bone mineral density in primary hyperparathyroidism. Clinical Endocrinology 201481 350-355. (doi:10.1111/cen.12472)

57 Putnam R, Dhibar DP, Varshney S, Behera A, Mittal BR, Bhansali A, Rao SD \& Bhadada SK. Effect of curative parathyroidectomy on insulin resistance. Indian Journal of Endocrinology and Metabolism 2016 20 784-789. (doi:10.4103/2230-8210.192916)

58 Almqvist EG, Bondeson AG, Bondeson L, Mellström D \& Svensson $\mathrm{J}$. Factors influencing insulin sensitivity in patients with mild primary hyperparathyroidism before and after parathyroidectomy. Scandinavian Journal of Clinical and Laboratory Investigation 201272 92-99. (doi:10.3109/00365513.2011.634432)

59 Farahnak P, Lärfars G, Sten-Linder M \& Nilsson IL. Mild primary hyperparathyroidism: vitamin D deficiency and cardiovascular risk markers. Journal of Clinical Endocrinology and Metabolism 201196 2112-2118. (doi:10.1210/jc.2011-0238)

60 Ayturk S, Gursoy A, Bascil Tutuncu N, Ertugrul DT \& Guvener Demirag N. Changes in insulin sensitivity and glucose and bone metabolism over time in patients with asymptomatic primary hyperparathyroidism. Journal of Clinical Endocrinology and Metabolism 200691 4260-4263. (doi:10.1210/jc.2005-2825)

61 Hagström E, Lundgren E, Rastad J \& Hellman P. Metabolic abnormalities in patients with normocalcemic hyperparathyroidism detected at a population-based screening. European Journal of Endocrinology 2006155 33-39. (doi:10.1530/eje.1.02173) 
62 Diri H, Unluhizarci K \& Kelestimur F. Investigation of glucose intolerance in patients with normocalcemic primary hyperparathyroidism: 4-year follow-up. Endocrine 201447 971-972. (doi:10.1007/s12020-014-0263-5)

63 Hagström E, Michaëlsson K, Melhus H, Hansen T, Ahlström H, Johansson L, Ingelsson E, Sundström J, Lind L \& Arnlöv J. Plasmaparathyroid hormone is associated with subclinical and clinical atherosclerotic disease in 2 community-based cohorts. Arteriosclerosis, Thrombosis, and Vascular Biology 201434 1567-1573. (doi:10.1161/ atvbaha.113.303062)

64 Baykan M, Erem C, Erdoğan T, Hacihasanoğlu A, Gedikli O, Kiriş A, Küçükosmanoğlu M, Ersöz HO \& Celik S. Impairment of flow mediated vasodilatation of brachial artery in patients with primary hyperparathyroidism. International Journal of Cardiovascular Imaging 200723 323-328. (doi:10.1007/s10554-006-9166-8)

65 Tuna MM, Doğan BA, Arduç A, Imga NN, Tütüncü Y, Berker D \& Güler S. Impaired endothelial function in patients with mild primary hyperparathyroidism improves after parathyroidectomy. Clinical Endocrinology 201583 951-956. (doi:10.1111/cen.12666)

66 Carrelli AL, Walker MD, Di Tullio MR, Homma S, Zhang C, McMahon DJ \& Silverberg SJ. Endothelial function in mild primary hyperparathyroidism. Clinical Endocrinology 201378 204-209. (doi:10.1111/j.1365-2265.2012.04485.x)

67 Dural C, Okoh AK, Seicean A, Yigitbas H, Thomas G, Yazici P, Shoenhagen P, Doshi K, Halliburton S \& Berber E. A pilot study investigating the effect of parathyroidectomy on arterial stiffness and coronary artery calcification in patients with primary hyperparathyroidism. Surgery 2016159 218-224. (doi:10.1016/j. surg.2015.07.037)

68 Rosa J, Raska I Jr, Wichterle D, Petrak O, Strauch B, Somloova Z, Zelinka T, Holaj R \& Widimsky J Jr. Pulse wave velocity in primary hyperparathyroidism and effect of surgical therapy. Hypertension Research 201134 296-300. (doi:10.1038/hr.2010.232)

69 Rubin MR, Maurer MS, McMahon DJ, Bilezikian JP \& Silverberg SJ. Arterial stiffness in mild primary hyperparathyroidism. Journal of Clinical Endocrinology and Metabolism 200590 3326-3330. (doi:10.1210/jc.2004-1400)

70 Smith JC, Page MD, John R, Wheeler MH, Cockcroft JR, Scanlon MF \& Davies JS. Augmentation of central arterial pressure in mild primary hyperparathyroidism. Journal of Clinical Endocrinology and Metabolism 200085 3515-3519. (doi:10.1210/jcem.85.10.6880)

71 Schillaci G, Pucci G, Pirro M, Monacelli M, Scarponi AM, Manfredelli MR, Rondelli F, Avenia N \& Mannarino E. Largeartery stiffness: a reversible marker of cardiovascular risk in primary hyperparathyroidism. Atherosclerosis 2011218 96-101. (doi:10.1016/j.atherosclerosis.2011.05.010)

72 Cansu GB, Yılmaz N, Özdem S, Balcı MK, Süleymanlar G, Arıcı C, Boz A, Sarı R \& Altunbaş HA. Parathyroidectomy in asymptomatic primary hyperparathyroidism reduces carotid intima-media thickness and arterial stiffness. Clinical Endocrinology 201684 39-47. (doi:10.1111/cen.12952)

73 Grundy SM, Cleeman JI, Daniels SR, Donato KA, Eckel RH, Franklin BA, Gordon DJ, Krauss RM, Savage PJ, Smith SC Jr et al. Diagnosis and management of the metabolic syndrome: an American heart association/national heart, lung, and blood institute scientific statement. Circulation 2005112 2735-2752. (doi:10.1161/ CIRCULATIONAHA.105.169404)

74 Tassone F, Gianotti L, Baffoni C, Cesario F, Magro G, Pellegrino M, Emmolo I, Maccario M \& Borretta G. Prevalence and characteristics of metabolic syndrome in primary hyperparathyroidism. Journal of Endocrinological Investigation 2012 35 841-846. (doi:10.3275/8192)

75 Mendoza-Zubieta V, Gonzalez-Villaseñor GA, Vargas-Ortega G, Gonzalez B, Ramirez-Renteria C, Mercado M, Molina-Ayala MA \& Ferreira-Hermosillo A. High prevalence of metabolic syndrome in a mestizo group of adult patients with primary hyperparathyroidism
(PHPT). BMC Endocrine Disorders 201515 16. (doi:10.1186/s12902015-0014.5)

76 Han D, Trooskin S \& Wang X. Prevalence of cardiovascular risk factors in male and female patients with primary hyperparathyroidism. Journal of Endocrinological Investigation 201235 548-552. (doi:10.3275/7861)

77 Luboshitzky R, Chertok-Schaham Y, Lavi I \& Ishay A. Cardiovascular risk factors in primary hyperparathyroidism. Journal of Endocrinological Investigation 200932 317-321. (doi:10.1007/BF03345719)

78 Delfini E, Petramala L, Caliumi C, Cotesta D, De Toma G, Cavallaro G, Panzironi G, Diacinti D, Minisola S, D'Erasmo E et al. Circulating leptin and adiponectin levels in patients with primary hyperparathyroidism. Metabolism 200756 30-36. (doi:10.1016/j. metabol.2006.08.019)

79 Pepe J, Cipriani C, Cilli M, Colangelo L \& Minisola S. Adipokines and bone metabolism: an interplay to untangle. Journal of Endocrinological Investigation 201639 1359-1361. (doi:10.1007/ s40618-016-0549-y)

80 Farahnak P, Ring M, Caidahl K, Farnebo LO, Eriksson MJ \& Nilsson IL. Cardiac function in mild primary hyperparathyroidism and the outcome after parathyroidectomy. European Journal of Endocrinology 2010163 461-467. (doi:10.1530/EJE-10-0201)

81 Walker MD, Fleischer JB, Di Tullio MR, Homma S, Rundek T, Stein EM, Zhang C, Taggart T, McMahon DJ \& Silverberg SJ. Cardiac structure and diastolic function in mild primary hyperparathyroidism. Journal of Clinical Endocrinology and Metabolism 201095 2172-2179. (doi:10.1210/jc.2009-2072)

82 Persson A, Bollerslev J, Rosen T, Mollerup CL, Franco C, Isaksen GA, Ueland T, Jansson S, Caidahl K \& SIPH Study Group. Effect of surgery on cardiac structure and function in mild primary hyperparathyroidism. Clinical Endocrinology 201174 174-180. (doi:10.1111/j.1365-2265.2010.03909.x)

83 Ozdemir D, Kalkan GY, Bayram NA, Onal ED, Ersoy R, Bozkurt E \& Cakir B. Evaluation of left ventricle functions by tissue doppler, strain, and strain rate echocardiography in patients with primary hyperparathyroidism. Endocrine 201447 609-617. (doi:10.1007/ s12020-014-0245-7)

84 Levy D, Garrison RJ, Savage DD, Kannel WB \& Castelli WP. Prognostic implications of echocardiographically determined left ventricular mass in the Framingham Heart Study. New England Journal of Medicine 1990322 1561-1566. (doi:10.1056/ NEJM199005313222203)

85 McMahon DJ, Carrelli A, Palmeri N, Zhang C, Di Tullio M, Silverberg SJ \& Walker MD. Effect of parathyroidectomy upon left ventricular mass in primary hyperparathyroidism: a meta-analysis. Journal of Clinical Endocrinology and Metabolism 2015100 4399-4407. (doi:10.1210/jc.2015-3202)

86 Verheyen N, Meinitzer A, Grübler MR, Ablasser K, Kolesnik E, Fahrleitner-Pammer A, Belyavskiy E, Trummer C, Schwetz V, Pieske-Kraigher E et al. Low-grade inflammation and tryptophankynurenine pathway activation are associated with adverse cardiac remodeling in primary hyperparathyroidism: the EPATH trial. Clinical Chemistry and Laboratory Medicine 201755 1034-1042. (doi:10.1515/CCLM-2016-1159)

87 Verheyen N, Fahrleitner-Pammer A, Belyavskiy E, Gruebler MR, Dimai HP, Amrein K, Ablasser K, Martensen J, Catena C, Pieske-Kraigher E et al. Relationship between bone turnover and left ventricular function in primary hyperparathyroidism: the EPATH trial. PLOS ONE 201712 e0173799. (doi:10.1371/journal.pone.0173799)

88 Iwata S, Walker MD, Di Tullio MR, Hyodo E, Jin Z, Liu R, Sacco RL, Homma $S$ \& Silverberg SJ. Aortic valve calcification in mild primary hyperparathyroidism. Journal of Clinical Endocrinology and Metabolism 201297 132-137. (doi:10.1210/jc.2011-2107)

89 Lind L \& Ljunghall S. Serum calcium and the ECG in patients with primary hyperparathyroidism. Journal of Electrocardiology 199427 99-103. (doi:10.1016/S0022-0736(05)80092-5) 
90 Napolitano C, Bloise R, Monteforte N \& Priori SG. Sudden cardiac death and genetic ion channelopathies: long QT, Brugada, short QT, catecholaminergic polymorphic ventricular tachycardia, and idiopathic ventricular fibrillation. Circulation 2012125 2027-2034. (doi:10.1161/ CIRCULATIONAHA.111.055947)

91 Zhang Y, Post WS, Dalal D, Blasco-Colmenares E, Tomaselli GF \& Guallar E. QT-interval duration and mortality rate: results from the Third National Health and Nutrition Examination Survey. Archives of Internal Medicine 2011171 1727-1733. (doi:10.1001/ ARCHINTERNMED.2011.433)

92 Chang CJ, Chen SA, Tai CT, Yu WC, Chen YJ, Tsai CF, Hsieh MH, Ding YA \& Chang MS. Ventricular tachycardia in a patient with primary hyperparathyroidism. Pacing and Clinical Electrophysiology 200023 534-537. (doi:10.1111/j.1540-8159.2000.tb00842.x)

93 Kiewiet RM, Ponssen HH, Janssens EN \& Fels PW. Ventricular fibrillation in hypercalcaemic crisis due to primary hyperparathyroidism. Netherland Journal of Medicine 200462 94-96.

94 Pepe J, Curione M, Morelli S, Colotto M, Varrenti M, Castro C, D'Angelo A, Cipriani C, Piemonte S, Romagnoli E et al. Arrhythmias in primary hyperparathyroidism evaluated by exercise test. European Journal of Clinical Investigation 201343 208-214. (doi:10.1111/eci.12038)

95 Pepe J, Curione M, Morelli S, Varrenti M, Cammarota C, Cilli M, Piemonte S, Cipriani C, Savoriti C, Raimo O et al. Parathyroidectomy eliminates arrhythmic risk in primary hyperparathyroidism, as evaluated by exercise test. European Journal of Endocrinology 2013169 255-261. (doi:10.1530/EJE-13-0293)

96 Birgander M, Juul-Möller S, Bondeson AG, Bondeson L \& Rydberg E. Adrenergic and cardiac dysfunction in primary hyperparathyroidism. Clinical Endocrinology 201276 189-195. (doi:10.1111/j.13652265.2011.04169.x)

97 Curione M, Letizia C, Amato S, Di Bona S, Di Fazio F, Minisola S, Mazzuoli G \& D'Erasmo E. Increased risk of cardiac death in primary hyperparathyroidism: what is a role of electrical instability? International Journal of Cardiology 2007121 200-202. (doi:10.1016/j. ijcard.2006.08.072)

98 Curione M, Amato S, Di Bona S, Petramala L, Cotesta D \& Letizia C. Parathyroidectomy erase increased myocardial electrical vulnerability in patients with primary hyperparathyroidism. International Journal of Cardiology 2010141 201-202. (doi:10.1016/j.ijcard.2008.11.067)

99 Nuzzo V, Tauchmanovà L, Fonderico F, Trotta R, Fittipaldi MR, Fontana D, Rossi R, Lombardi G, Trimarco B \& Lupoli G. Increased intima-media thickness of the carotid artery wall, normal blood pressure profile and normal left ventricular mass in subjects with primary hyperparathyroidism. European Journal of Endocrinology 2002 147 453-459. (doi:10.1530/eje.0.1470453)

100 Walker MD, Fleischer J, Rundek T, McMahon DJ, Homma S, Sacco R \& Silverberg SJ. Carotid vascular abnormalities in primary hyperparathyroidism. Journal of Clinical Endocrinology and Metabolism 200994 3849-3856. (doi:10.1210/jc.2009-1086)

101 Fallo F, Camporese G, Capitelli E, Andreozzi GM, Mantero F \& Lumachi F. Ultrasound evaluation of carotid artery in primary hyperparathyroidism. Journal of Clinical Endocrinology and Metabolism 200388 2096-2099. (doi:10.1210/jc.2002-021837)

102 Kosch M, Hausberg M, Vormbrock K, Kisters K, Rahn KH \& Barenbrock M. Studies on flow-mediated vasodilation and intimamedia thickness of the brachial artery in patients with primary hyperparathyroidism. American Journal of Hypertension 200013 759-764. (doi:10.1016/S0895-7061(00)00248-X)

103 Kosch M, Hausberg M, Barenbrock M, Posadzy-Malaczynska A, Kisters K \& Rahn KH. Arterial distensibility and pulse wave velocity in patients with primary hyperparathyroidism before and after parathyroidectomy. Clinical Nephrology 200155 303-308.

104 Lumachi F, Ermani M, Frego M, Pilon F, Filosa T, Di Cristofaro L, De Lotto F \& Fallo F. Intima-media thickness measurement of the carotid artery in patients with primary hyperparathyroidism. A prospective case-control study and long-term follow-up. In Vivo 200620 887-890.

105 Ring M, Farahnak P, Gustavsson T, Nilsson IL, Eriksson MJ \& Caidahl K. Arterial structure and function in mild primary hyperparathyroidism is not directly related to parathyroid hormone, calcium, or vitamin D. PLoS ONE 20127 e39519. (doi:10.1371/ journal.pone.0039519)

106 Walker MD, Rundek T, Homma S, Ditullio M, Iwata S, Lee JA, Choi J, Liu R, Zhang C, McMahon DJ et al. Effect of parathyroidectomy on subclinical cardiovascular disease in mild primary hyperparathyroidism. European Journal of Endocrinology 2012167 277-285. (doi:10.1530/EJE12-0124)

107 Pepe J, Diacinti D, Fratini E, Nofroni I, D'Angelo A, Pilotto R, Savoriti C, Colangelo L, Raimo O, Cilli M et al. High prevalence of abdominal aortic calcification in patients with primary hyperparathyroidism as evaluated by Kauppila score. European Journal of Endocrinology 2016175 95-100. (doi:10.1530/EJE-15-1152)

108 Streeten EA, Munir K, Hines S, Mohamed A, Mangano C, Ryan KA $\&$ Post W. Coronary artery calcification in patients with primary hyperparathyroidism in comparison with control subjects from the multi-ethnic study of atherosclerosis. Endocrine Practice 200814 155-161. (doi:10.4158/EP.14.2.155)

109 Osto E, Fallo F, Pelizzo MR, Maddalozzo A, Sorgato N, Corbetti F, Montisci R, Famoso G, Bellu R, Lüscher TF et al. Coronary microvascular dysfunction induced by primary hyperparathyroidism is restored after parathyroidectomy. Circulation 2012126 1031-1039. (doi:10.1161/CIRCULATIONAHA.111.081307)

110 Marini C, Giusti M, Armonino R, Ghigliotti G, Bezante G, Vera L, Morbelli S, Pomposelli E, Massollo M, Gandolfo P et al. Reduced coronary flow reserve in patients with primary hyperparathyroidism: a study by G-SPECT myocardial perfusion imaging. European Journal of Nuclear Medicine Molecular Imaging 201037 2256-2263. (doi:10.1007/s00259-010-1599-6)

111 Dural C, Okoh AK, Seicean A, Yigitbas H, Thomas G, Yazici P, Shoenhagen P, Doshi K, Halliburton S \& Berber E. A pilot study investigating the effect of parathyroidectomy on arterial stiffness and coronary artery calcification in patients with primary hyperparathyroidism. Surgery 2016 159 218-224. (doi:10.1016/j.surg.2015.07.037)

112 Kepez A, Harmanci A, Hazirolan T, Isildak M, Kocabas U, Ates A, Ciftci O, Tokgozoglu L \& Gürlek A. Evaluation of subclinical coronary atherosclerosis in mild asymptomatic primary hyperparathyroidism patients. International Journal of Cardiovascular Imaging 200925 187-193. (doi:10.1007/s10554-008-9369-2)

113 Clifton-Bligh PB, Nery ML, Supramaniam R, Reeve TS, Delbridge L, Stiel JN, McElduff A, Wilmshurst EG, Robinson BG, Fulcher GR et al. Mortality associated with primary hyperparathyroidism. Bone 2015 74 121-124. (doi:10.1016/j.bone.2014.12.067)

114 Yu N, Donnan PT, Flynn RW, Murphy MJ, Smith D, Rudman A $\&$ Leese GP. Increased mortality and morbidity in mild primary hyperparathyroid patients. The Parathyroid Epidemiology and Audit Research Study (PEARS). Clinical Endocrinology 201073 30-34. (doi:10.1111/J.1365-2265.2009.03766.x)

115 Wermers RA, Khosla S, Atkinson EJ, Grant CS, Hodgson SF, O'Fallon WM \& Melton LJ 3rd. Survival after the diagnosis of hyperparathyroidism: a population based study. American Journal of Medicine 1998104 115-122. (doi:10.1016/S0002-9343(97)00270-2)

116 Soreide JA, van Heerden JA, Grant CS, Yau LoC, Schleck C \& Ilstrup DM. Survival after surgical treatment for primary hyperparathyroidism. Surgery 1997122 1117-1123. (doi:10.1016/ S0039-6060(97)90216-6)

117 Yu N, Leese GP \& Donnan PT. What predicts adverse outcomes in untreated primary hyperparathyroidism? The Parathyroid Epidemiology and Audit Research Study (PEARS). Clinical Endocrinology 201379 27-34. (doi:10.1111/cen.12206)

118 van Ballegooijen AJ, Reinders I, Visser M \& Brouwer IA. Parathyroid hormone and cardiovascular disease events: a systematic review and 
meta-analysis of prospective studies. American Heart Journal 2013 165 655-664. (doi:10.1016/j.ahj.2013.02.014)

119 Walker MD, Rubin M \& Silverberg SJ. Nontraditional manifestations of primary hyperparathyroidism. Journal of Clinical Densitometry 201316 40-47. (doi:10.1016/j.jocd.2012.11.008)

120 De Lucia F, Minisola S, Romagnoli E, Pepe J, Cipriani C, Scillitani A, Parikh N \& Rao DS. Effect of gender and geographic location on the expression of primary hyperparathyroidism. Journal of Endocrinological Investigation 201336 123-126. (doi:10.3275/8455)

121 Minisola S, Pepe J, Scillitani A \& Cipriani C. Explaining geographical variation in the presentation of primary hyperparathyroidism. Lancet Diabetes and Endocrinology 20164 641-643. (doi:10.1016/s22138587(16)00076-0)

122 Hu S, Cai X, Mewani V, Wong B, Trooskin S \& Wang X. Impact of ethnic background on clinical characteristics and cardiovascular risk factors among patients with primary hyperparathyroidism. Endocrine Practice 201622 323-327. (doi:10.4158/EP15951.OR)

123 Pepe J, Cipriani C, Pilotto R, De Lucia F, Castro C, Lenge L, Russo S, Guarnieri V, Scillitani A, Carnevale V et al. Sporadic and hereditary primary hyperparathyroidism. Journal of Endocrinological Investigation 201134 40-44.

124 Eller-Vainicher C, Chiodini I, Battista C, Viti R, Mascia ML, Massironi S, Peracchi M, D'Agruma L, Minisola S, Corbetta S et al. Sporadic and MEN1-related primary hyperparathyroidism: differences in clinical expression and severity. Journal of Bone and Mineral Research 200924 1404-1410. (doi:10.1359/jbmr.090304)

125 Cipriani C, Biamonte F, Costa AG, Zhang C, Biondi P, Diacinti D, Pepe J, Piemonte S, Scillitani A, Minisola S et al. Prevalence of kidney stones and vertebral fractures in primary hyperparathyroidism using imaging technology. Journal of Clinical Endocrinology and Metabolism 2015100 1309-1315. (doi:10.1210/jc.2014-3708)

Received 17 June 2017

Revised version received 14 August 2017

Accepted 31 August 2017 